\title{
RANKING OF EFFECTS OF CONSTRUCTION DELAY: EVIDENCE FROM MALAYSIAN BUILDING PROJECTS
}

\author{
K. Ullah a *, M. S. Khan ${ }^{\text {b }}$, M. T. Lakhiar ${ }^{\text {a }}$, A. A. Vighio ${ }^{\text {c }, ~ S . ~ S o h u ~}{ }^{\text {a }}$ \\ a Faculty of Civil and Environmental Engineering, Universiti Tun Hussein Onn Malaysia 86400 Parit Raja, Batu Pahat, Johor, \\ Malaysia, e-mail: kaleem9191@gmail.com \\ ${ }^{\mathrm{b}}$ Centre for Management \& Commerce, University of Swat, Pakistan \\ ${ }^{c}$ Department of Civil Engineering, Mehran University of Engineering \& Technology, Pakistan
}

Received: 06.01.2018 / Accepted: 15.02.2018 / Revised: 13.04.2018 / Available online: 31.05.2018

DOI: 10.2478/jaes-2018-0011

KEY WORDS: Delays, Effects, Construction Projects, Malaysian Building Projects.

\begin{abstract}
:
The problem of delay is a regular phenomenon in construction projects all around the world and the Malaysian building projects has no exclusion. The aim of this paper is to determine and rank the effects of delay in Malaysian building projects with respect to their Relative Importance Index. Literature review and questionnaire survey were used to gather data for this study. A thorough literature review was performed to identify the common effects of delays in building construction projects. A questionnaire was distributed among key project participants; contractors, clients and consultants, to rank the effects of delay in Malaysian building projects based on the perception of survey respondents. In total 300 questionnaires were distributed, as a result of 240 questionnaires were received. The collected data of questionnaire survey was analysed using statistical software SPSS. In total, 17 effects of the delays have been determined and findings from the survey revealed that time overrun, cost overrun, dispute, loss of profit, arbitration, claims, contract termination, litigation, poor quality of work, and total project abandonment were the main effects of delay in Malaysian building projects. The findings of this study might encourage construction stakeholders to focus on the issue of delays in building projects.
\end{abstract}

\section{INTRODUCTION}

Completion of construction projects before due date is one of an important parameter for successful construction projects. However, Delay is a very frequent phenomenon and rampant across the world in construction projects (Aziz, 2013). In Tanzania, Kikwasi (2012) found that $68 \%$ of the construction practitioners faced delays in projects they were engaged. Assaf \& Al-Hejji (2006) conducted a questionnaire survey in Saudi Arabia on delays in construction projects. Results of survey revealed that $70 \%$ of projects go through delay and that the average delay was between $10 \%$ and $30 \%$. In Nigeria, Amu \& Adesanya (2011) carried out a study on construction delays and concluded that $45 \%$ of sampled construction projects were failed to accomplish within the planned duration. The study of Senouci et al. (2016) revealed that in the state of Qatar, $72 \%$ of the public construction projects had a delay that was completed between 2000 and 2013.

Like other countries, the problem of delay is also associated with construction industry of Malaysia. Abdullah et al. (2010) cited that $90 \%$ of MARA construction projects completed beyond the planned dates. Azlan \& Syuhada (2014) found that in Malaysia, only 30\% of the public sector building projects were finished within the schedule dates. Sambasivan \& Soon (2007) examined delays in Malaysia construction industry, and stated that about $17.3 \%$ from the 417 government projects experienced delay.

There are several factors, which occur from the initial phase to the final phase of construction project causing delays. Failure to complete construction projects within targeted time, can leads to many unexpected effects on the projects. Literature reveals that various researchers have examined the causative factors and few researchers have perused the effects of delays in the building projects. Previous researches considered the causative factors and the effects of construction delays, integrated. Thus, this study aimed to focus on the effects of construction delays only and attempts to determine and rank the effects of delays in Malaysian building construction projects.

\section{CONSTRUCTION DELAYS AND ITS EFFECTS}

Construction delays can be defined in various ways. Delay is defined by Fugar \& Agyakwah-baah (2010) as "the time overrun, either beyond the date of completion specified by the contract or beyond the extended contract period where an

\footnotetext{
* Corresponding author: Kaleem Ullah, e-mail: kaleem9191@ gmail.com
} 
extension of time has been approved". According to Majid (2006) "delay is the late completion of construction projects compared to the stipulated schedule or agreed contract schedule".

Effects of construction delays are always debilitating on construction industry performance. Several studies were executed by researchers to evaluate the effects of delay in construction projects. A study was conducted by Aibinu \& Jagboro (2002) to assess the negative effects of delays on construction projects in Nigerian. A questionnaire was distributed to construction practitioners: owners, architects, consultants, contractors, and quantity surveyors. The findings of the survey showed that effects of delays in Nigerian construction projects were: time extension, cost increase, arbitration, disputes, litigation, and project termination.

Haseeb \& Bibi (2011) investigated the effects of delays in the construction industry of Pakistan by conduction a questionnaire survey among construction stakeholders and identified that schedule overrun, budget overrun, differences among construction stakeholders, arbitration, claims, litigation, and project abandonment as the effects of construction delays.

Denini (2012) examined the effects of delays in Libyan construction industry and argue that impacts of construction delay includes time overrun, cost overrun, claims, disputes, litigation, poor quality of work, decrease in the owner's financial commitment, arbitration, contract termination, total project abandonment.

Study of Tumi et al. (2009) identified that the construction delay have the following effects on construction projects: loss of profit; blacklist by authorities; cost overrun, time overrun, and bad reputation to construction stakeholders.

A research performed by Kikwasi (2012) on effects of delays in construction projects in Tanzania concluded that effects of delays includes time overrun, budget overrun, idling resources, disputes, arbitration, poor quality of work, loos of profit, bankruptcy, litigation, create stress to contractors, total abandonment, create stress to the clients, and acceleration losses.

\section{RESEARCH OBJECTIVE}

This study intended to 1) identify effects of delay in building projects; and 2) Quantify "relative importance index" of effects of delay, to demonstrate the ranking of effects of delay in Malaysian building projects.

\section{RESEARCH METHODOLOGY}

The research method of this study is listed as below:

1) Detailed review of previous researches was executed and further opinions from construction professionals were taken, through which seventeen effects of delays in construction industry were identified. The seventeen effects of construction delays were: time overrun, cost overrun, arbitration, disputes, total project abandonment, claims, poor quality of work, litigation, decrease in the owner's financial commitment, contract termination, loss of profit, blacklist by authorities, bad reputation to construction stakeholders, idling resources, create stress to the Clients, bankruptcy, and create stress to the contractors.

2) A questionnaire was developed comprising of two parts (A and $B$ ). Part $A$ requested general particulars of the respondents. Part B was intended to gather perception of construction professional about effects of delays in building construction projects. A five point Likert Scale was used for assessing the effects of construction delays in Malaysian building projects. The numerics values are assigned to the respondents' rating were: 1 =" not important", 2 = "slightly important", $3=$ "moderately important", 4 = "very important" and $5=$ "extremely important".

3) In order to check the content of the designed questionnaire, opinions from construction experts was taken. Experts included of one senior university professor from construction management, one constructor, one public client, and one project manager. All the experts have at least ten years of experience in building construction industry. Their valuable comments were used to improve the designed questionnaire.

4) In order to check relevancy level of effects of construction delays given in questionnaire to Malaysian building industry a pilot study was conducted. In pilot study, questionnaire was distributed to thirty construction practitioners. To determine whether effects of construction delays are relevant to Malaysian conditions, cut- off scale from Muhwezi et al. (2012) is adopted as presented in Table 1.

Table 1. Cut- off scale

\begin{tabular}{|c|c|}
\hline Mean Score & $\begin{array}{c}\text { Level of Relevancy } \\
\text { (Effects of delays) }\end{array}$ \\
\hline $3.00-5.00$ & Relevant \\
\hline$<3.00$ & Non Relevant \\
\hline
\end{tabular}

After the analysis of pilot study, results showed that the mean score of each effect of construction delay were above 3.00 , thus the designed questionnaire is relevant to Malaysian building industry.

5) The research targeted population comprises of owners, consultants, and contractors. Random sampling method was selected to make sure a representative sample of targeted population. Equation 1, adopted from Enshassi et al. (2010) was used to calculate the sample size for unlimited target population.

$$
S . S=\frac{z^{2} \times P \times(1-p)}{G^{2}}
$$

where:

S.S is sample size, $\mathrm{Z}$ is value for the confidence level i.e. 2.575 for $99 \%$ confidence level, $\mathrm{P}$ is percentage picking choice, since p is unknown; Sincich et al. (2002) proposed a conservative value of 0.50 to be used, $\mathrm{C}$ is margin of error (9\%). Using a $99 \%$ confidence level, the sample size is estimated as follows: 


$$
S . S=\frac{2.575^{2} \times 0.5 \times(1-0.5)}{0.09^{2}}=204.64 \approx 205 \text { Respondents }
$$

The final questionnaire was distributed to 300 construction practitioners involved in handling building projects in Malaysia.

6) The "Relative Importance Index" is used to rank the effects of construction delays. The relative importance index is calculated using equation (2) adopted from Jarkas and Bitar et al. (2012).

$$
\mathrm{RII}=\frac{\sum W}{A \times N}
$$

Where, RII is the "Relative Importance Index", W is the "weighting given to each effect by the respondents" (ranging from 1 to 5), "A" is the maximum weight (i.e. 5 in this case), and $\mathrm{N}$ is the total number of survey participants.

\section{DATA COLLECTION}

In total, 240 valid questionnaires were received of the 300 distributed questionnaires, yielding a response rate of 80 . The rate of response of contractors, consultants, and clients are $41.7 \%, 33.3 \%$, and $25 \%$ respectively. The demography of the survey respondents are given in Table 2 .

Table 2. Information of survey respondents

\begin{tabular}{|l|c|c|}
\hline Demographic characteristic & Responses & $\%$ \\
\hline Type of organization & 100 & 41.7 \\
contractors & 80 & 33.3 \\
consultants & 60 & 25 \\
clients & & \\
\hline Organization's sector & 192 & 80 \\
Private & 48 & 20 \\
Public & & \\
\hline Education & 38 & 15.83 \\
Diploma & 137 & 57.08 \\
Bachelor degree & 60 & 25 \\
Master & & \\
\hline
\end{tabular}

\begin{tabular}{|l|c|c|}
\hline Phd & 5 & 2.08 \\
\hline Occupational level & 93 & 38.75 \\
Executive & 35 & 14.58 \\
Non-executive & 112 & 46.67 \\
Managerial & & \\
\hline Working experience & 46 & 19.17 \\
Less than 10 years & 74 & 30.83 \\
10-20 years & 120 & 50 \\
More than 20 years & & \\
\hline Size of projects based on contract & & \\
amount & 63 & 26.25 \\
Less than RM 5 millions & 72 & 30 \\
RM 5 million-RM 10 millions & 105 & 43.75 \\
More than RM 10 millions
\end{tabular}

\section{DATA ANALYSIS AND DISCUSSION}

The software SPSS 22 was used to analyse the collected data. Cronbach's alpha was used to measure the internal consistency of questionnaire. Litwin (1995) suggested that consistency is high when Cronbach alpha is above 0.7. Table 3 shows Cronbach's Alpha values of the questionnaire for overall effects of construction delays. This confirms that the consistency of the questionnaire is high.

Table 3. Cranach's Alpha for Effects of Construction Delays

\begin{tabular}{|c|c|}
\hline Cranach's Alpha & N of Items \\
\hline 0.773 & 17 \\
\hline
\end{tabular}

\subsection{Ranking of Effects of Construction Delays}

The effects of construction delays were ranked based on their relative importance index. Ranking of effects of delays, enabled to identify the main effects of delays in Malaysian building projects. Table 4 lists the results of survey for effects of delay in Malaysian building construction projects. While, table 5, extracts the top five effects of construction delays based on the responses of the three parties.

\begin{tabular}{|c|c|c|c|c|c|c|c|c|}
\hline \multirow{2}{*}{ Effects of Construction Delays } & \multicolumn{2}{|c|}{ Contractor } & \multicolumn{2}{|c|}{ Consultant } & \multicolumn{2}{|c|}{ Client } & \multicolumn{2}{|c|}{ Overall } \\
\hline & RII & $\mathrm{R}$ & RII & $\mathrm{R}$ & RII & $\mathrm{R}$ & RII & $\mathrm{R}$ \\
\hline Time overrun & 0.906 & 1 & 0.913 & 1 & 0.956 & 1 & 0.925 & 1 \\
\hline Cost overrun & 0.9 & 2 & 0.877 & 3 & 0.953 & 2 & 0.91 & 2 \\
\hline Litigation & 0.702 & 11 & 0.74 & 10 & 0.86 & 3 & 0.767 & 8 \\
\hline Total project abandonment & 0.732 & 10 & 0.833 & 6 & 0.687 & 10 & 0.751 & 10 \\
\hline Dispute & 0.834 & 4 & 0.885 & 2 & 0.807 & 5 & 0.842 & 3 \\
\hline Claims & 0.798 & 7 & 0.875 & 4 & 0.733 & 8 & 0.802 & 6 \\
\hline Create stress to the contractors & 0.736 & 8 & 0.68 & 15 & 0.63 & 15 & 0.682 & 13 \\
\hline Contract termination & 0.876 & 3 & 0.753 & 9 & 0.763 & 7 & 0.797 & 7 \\
\hline Poor quality of work & 0.782 & 9 & 0.833 & 6 & 0.68 & 11 & 0.765 & 9 \\
\hline Loss of profit & 0.818 & 5 & 0.843 & 5 & 0.777 & 6 & 0.812 & 4 \\
\hline Decrease in the owner's financial commitment & 0.656 & 15 & 0.727 & 11 & 0.643 & 13 & 0.675 & 14 \\
\hline Bad reputation to construction stakeholders & 0.63 & 17 & 0.825 & 7 & 0.58 & 17 & 0.678 & 12 \\
\hline
\end{tabular}

Table 4. Ranking of effects of construction delay 


\begin{tabular}{|l|c|c|c|c|c|c|c|c|}
\hline Idling resources & 0.698 & 13 & 0.725 & 12 & 0.603 & 16 & 0.675 & 15 \\
\hline Arbitration & 0.814 & 6 & 0.785 & 8 & 0.813 & 4 & 0.804 & 5 \\
\hline Blacklist by authorities & 0.66 & 14 & 0.68 & 15 & 0.673 & 12 & 0.671 & 16 \\
\hline Bankruptcy & 0.638 & 16 & 0.685 & 14 & 0.64 & 14 & 0.548 & 17 \\
\hline Create stress to the clients & 0.7 & 12 & 0.695 & 13 & 0.697 & 9 & 0.697 & 11 \\
\hline
\end{tabular}

Table 5. Extract of the Five Most Important Effects of Construction Delay

\begin{tabular}{|c|c|c|}
\hline Contractor & Consultant & Client \\
\hline Time Overrun, & Time Overrun, & Time Overrun, \\
\hline Cost Overrun & Dispute & Cost Overrun \\
\hline Contract Termination & Cost Overrun & Litigation \\
\hline Dispute & Claims & Dispute \\
\hline Loss of Profit & Loss of Profit & \\
\hline
\end{tabular}

Table 4 shows that all parties agreed that "time overrun" is the prime effects of delays in Malaysian building projects with overall RII of 0.925 . Time overrun can be defined as "the time increased to finish the construction project after scheduled date which is affected by internal and external causes surrounded the construction project" (Al-Najjar, 2008). The "cost overrun" received the second ranks by the contractor and the client, while the consultant gave it 3rd rank. The "Time Overrun" received 2nd in the overall ranking with RII of 0.91 . Cost overrun occurs when the final cost of the project at completion time is higher than projected cost. The overall ranking shows the "dispute" as the third effect of delay with RII of 0.842 . This effect was ranked second by the consultant, fourth by the contractor, and fifth by the client. When construction projects are not completed within planned time it give rise to disputes among construction stake holders. If issues regarding delays are not solved on time by construction parties, it leads to total abandonment of the project. "Dispute" is at the fifth rank according to the overall perspective, dispute among construction stakeholders occurs when losses are experienced in project through delays.

\subsection{Spearman's Rank Correlation coefficient}

Spearman's rank correlation coefficient is used to show whether there is the agreement or disagreement among the groups of respondent (Tikote et al., 2017). The value correlation coefficient ranges between +1 and -1 , Where +1 indicates absolute positive relationship (agreement), while -1 implies a negative relationship (disagreement). Table 6 illustrates the results of Spearman coefficient computed by using SPSS version 22. Spearman coefficient in Table 6 shows that there is a strong agreement between three groups of respondents i.e. contractors, clients, and consultants in ranking the effects of construction delays.

Table 6. Spearman rank correlation coefficient

\begin{tabular}{|l|c|c|}
\hline \multicolumn{1}{|c|}{ Parties } & $\begin{array}{c}\text { Spearman rank } \\
\text { correlation } \\
\text { coefficient }\end{array}$ & $\begin{array}{c}\text { Significance } \\
\text { level }\end{array}$ \\
\hline Contractors- Consultants & 0.701 & 0.000 \\
\hline Contractors - Clients & 0.801 & 0.000 \\
\hline Consultants - Clients & 0.636 & 0.000 \\
\hline
\end{tabular}

\section{COMPARISON WITH PREVIOUS SELECTED STUDIES}

The objective of this part is to get a general view about the effects of delays among some selected countries through an examination of five major effects from this survey and three different selected previous studies. The studies of Aibinu \& Jagboro (2002) in Nigeria, Tumi et al. (2009) in Libya, and Kikwasi (2012) in Tanzania were selected for comparisons. Although methods of survey and purposes of these studies are not definitely similar, the comparison is worthful to understand clearly the problem of effects of delay in construction projects of developing countries.

Comparison among this study, research of Aibinu \& Jagboro (2002), and research of Kikwasi (2012) showed that in these studies the top two effects of delays: time overrun and cost overrun are same. However, in the study of Tumi et al. (2009) interestingly the top two effects of delay were: loss of interest by the stakeholder and blacklist by authorities while, cost and time overruns were ranked third and fourth. Table 7 shows that dispute is one of the main effects of delay as it can be seen at rank 3 in this study and research of Aibinu \& Jagboro (2002), while, ranked 5 at the study of Kikwasi (2012). Arbitration is not only one of the main effects of delay in Malaysia but also in Nigeria.

The comparison of this study with research of other countries concludes that the five most effects of delay in Malaysia building construction industry, also turn up in different developing countries. 
Table 7. Comparisons with Previous Studies

\begin{tabular}{|c|c|c|c|}
\hline $\begin{array}{c}\text { Malaysia } \\
\text { This Study }\end{array}$ & $\begin{array}{c}\text { Nigeria } \\
\text { (Aibinu \& } \\
\text { Jagboro, } \\
\text { 2002) }\end{array}$ & $\begin{array}{c}\text { Libya } \\
\text { (Tumi et al., } \\
\text { 2009) }\end{array}$ & $\begin{array}{c}\text { Tanzania } \\
\text { (Kikwasi, } \\
\text { 2012) }\end{array}$ \\
\hline $\begin{array}{c}\text { Time } \\
\text { Overrun }\end{array}$ & $\begin{array}{c}\text { Time } \\
\text { overrun }\end{array}$ & $\begin{array}{c}\text { Loss of interest } \\
\text { by the } \\
\text { stakeholder }\end{array}$ & $\begin{array}{c}\text { Time } \\
\text { overrun }\end{array}$ \\
\hline $\begin{array}{c}\text { Cost } \\
\text { Overrun }\end{array}$ & Cost overrun & $\begin{array}{c}\text { Blacklist by } \\
\text { authorities }\end{array}$ & Cost overrun \\
\hline Dispute & Dispute & $\begin{array}{c}\text { Time overrun } \\
\text { social } \\
\text { impact }\end{array}$ \\
\hline $\begin{array}{c}\text { Loss of } \\
\text { Profit }\end{array}$ & Arbitration & $\begin{array}{c}\text { Cost overrun } \\
\text { resources }\end{array}$ \\
\hline Arbitration & Litigation & $\begin{array}{c}\text { Declination of } \\
\text { reputation }\end{array}$ & Dispute \\
\hline
\end{tabular}

\section{CONCLUSIONS}

Delay is one of the main problems in building construction projects. Through literature showed that there are various effects of construction delays. This research has identified seventeen effects of delay in Building construction projects in Malaysia. The explored main effects of delay were time overrun, cost overrun, dispute, loss of profit, and arbitration. As an important contribution, we also studied the comparison of effects of delay in various countries. We believe that the findings presented in this study can be useful for construction practitioners to cope with the problem of delays. Finally, similar studies can be carried out in various types of construction projects, such as highways projects, dam projects, ports projects.

\section{REFERENCES}

Abdullah, M. R., Rahman, I. A., \& Azis, A. A. A., 2010. Causes of Delay in MARA Management Procurement Construction Projects. Journal of Surveying, Construction \& Property, 1(1), 123-138.

Aibinu, A. A., \& Jagboro, G. O., 2002. The effects of construction delays on project delivery in Nigerian construction industry. International Journal of Project Management, 20(8), 593-599.

Al-Najjar, J., 2008. Factors influencing time and cost overruns on construction projects in the Gaza Strip. The Islamic University of Gaza Master Thesis.

Amu, O. O., \& Adesanya, D. A., 2011. Mathematical expressions for explaining project delays in south western Nigeria. Singapore Journal of Scientific Research, 1(1), 5967.

Assaf, S. A., \& Al-Hejji, S., 2006. Causes of delay in large construction projects. International Journal of Project Management, 24(4), 349-357.

Aziz, R. F., 2013. Ranking of delay factors in construction projects after Egyptian revolution. Alexandria Engineering Journal, 52(3), 387-406.
Azlan, O., \& Syuhada, I., 2014. Delay in Government Project Delivery in Kedah, Malaysia. In Recent Advances in Civil Engineering and Mechanics (pp. 248-254).

Denini, F., 2012. Causes, effects and methods of minimizing delays on large construction projects in Libya. In $6^{\text {th }}$ International Conference and Workshop on the Built Environment in Developing Countries. Adelaide, Australia.

Enshassi, A., Kumaraswamy, M., \& Al-najjar, J., 2010. Significant Factors Causing Time and Cost Overruns in Construction Projects in the Gaza Strip: Contractors' Perspective. International Journal of Construction Management, 10(1), 35-60.

Fugar, F. D. K., \& Agyakwah-baah, A. B., 2010. Delays in building construction projects in Ghana. Australasian Journal of Construction Economics and Building, 10(1/2), 103-116.

Haseeb, M., \& Bibi, A., 2011. Problems of Projects and Effects of Delays in the Construction Industry of Pakistan. Australian Journal of Business and Management Research, $1(5), 41-50$

Jarkas, A. M., \& Bitar, C. G., 2012. Factors Affecting Construction Labor Productivity in Kuwait. Journal of Construction Engineering and Management, 138(7), 811820.

Kikwasi, G. J., 2012. Causes and Effects of Delays and Disruptions in Construction Projects in Tanzania. Australasian Journal of Construction Economics and Building, 1(2), 52-59.

Litwin, M. S., 1995. How to Measure Survey Reliability and Validity. Thousand Oaks, Calif, USA: Sage.

Majid, I. A., 2006. Causes and effects of delays in Aceh construction Industry. Master Thesis, Universiti Teknologi Malaysia.

Muhwezi, L., Chamuriho, L. M., \& Lema, N. M., 2012. An investigation into materials wastes on building construction projects in Kampala, Uganda. Scholarly Journal of Engineering Research, 1(1), 11-18.

Sambasivan, M., \& Soon, Y. W., 2007. Causes and effects of delays in Malaysian construction industry. International Journal of Project Management, 25(5), 517-526.

Senouci, A., Ismail, A., \& Eldin, N., 2016. Time Delay and Cost Overrun in Qatari Public Construction Projects. Procedia Engineering, 164, 368-375.

Sincich, T. L., Levine, D. M., \& Stephan, D. F., 2002. Practical Statistics by Example Using Microsoft Excel and Minitab. (Second, Ed.). Prentice Hall, Upper Saddle River, New Jersey.

Tikote, R., Magdum, M., \& Khandare, M., 2017. Delay Analysis in Industrial Projects by Using Relative Importance 
Index Method. International Research Journal of Engineering and Technology, 4(6), 1982-1988.

Tumi, S. A. H., Omran, A., \& Pakir, A. H. K., 2009. Causes of Delay in Construction Industry in Libya. In The International Conference on Economics and Administration (pp. 265-272). Romania. 